\title{
ANALISIS FAKTOR YANG BERHUBUNGAN DENGAN KEJADIAN STROKE DI RSUD INDRAMAYU
}

\author{
${ }^{1}$ Wayunah, ${ }^{2}$ Muhammad Saefulloh \\ ${ }^{1}$ Prodi Ners, STIKes Indramayu \\ ${ }^{2}$ Prodi Ilmu Keperawatan, STIKes Indramayu \\ Email : ${ }^{1}$ ayoun_plumbon@yahoo.com
}

\begin{abstract}
ABSTRAK
Stroke merupakan penyakit neurologik yeng terjadi karena gangguan suplai darah menuju suatu bagian otak. Angka kejadian stroke meningkat seiring dengan bertambahnya usia, semakin tinggi usia seseorang semakin tinggi kemungkinan terjadi stroke. Menurut penyebabnya stroke dibagi dua yaitu stroke hemoragik akibat pecahnya pembuluh darah otak dan stroke iskemik (stroke non hemoragik) akibat adanya trombus atau embolus pada pembuluh darah otak. Banyak faktor yang menyebabkan stroke, yang terdiri dari faktor yang tidak dapat diubah dan faktor yang dapat diubah. Tujuan penelitian untuk mengidentifikasi dan menjelaskan faktor risiko yang berhubungan dengan kejadian stroke. Penelitian ini merupakan penelitian observasonal analitik dengan rancangan cross sectional study. Sampel sebanyak 103 responden yang diambil dengan tehnik consecutive sampling. Hasil penelitian menunjukkan ada hubungan yang signifikan antara hipertensi $(\mathrm{p}=0,035)$ dan aktivitas fisik $(\mathrm{p}=0,011)$ dengan jenis stroke. Aktivitas fisik merupakan faktor risiko paling dominan yang berhubungan dengan jenis stroke dengan $\mathrm{OR}=5,8$. Penelitian ini menyimpulkan riwayat hipertensi dan aktivitas fisik merupakan faktor risiko independen yang berhubungan dengan jenis stroke. Rekomendasi dari penelitian ini ditujukan kepada rumah sakit untuk meningkatkan kegiatan penyuluhan untuk mencegah faktor risiko terjadinya stroke. Selain itu meningkatkan peran perawat dalam pemberian pelayanan keperawatan, dimana perawat memfokuskan asuhan pada kebutuhan kesehatan pasien secara holistik.
\end{abstract}

Kata kunci : Aktifitas fisik, faktor risiko, hipertensi \& stroke

\section{ABSTRACT}

Stroke is a neurological disease that occurs due to disruption of the blood supply to a part of the brain. The incidence of stroke increases with age, that the older the person the possibility of stroke. According to the cause of stroke divided into two hemorrhagic stroke due to rupture of blood vessels of the brain and ischemic stroke (stroke non hemoragik) due to thrombus or embolus in the blood vessels of the brain. Many factors cause a stroke, which consists of factors that can not be changed and the factors that can be changed. The aim of research to identify and explain the risk factors associated with the occurrence of stroke.This research is an analytic observational study with cross sectional study. The sample of this study as many as 103 respondents is taken with consecutive sampling technique. The results showed significant relationship between hypertension $(p=0,035)$ and physical activity $(p=0.011)$ with the type of stroke. Physical activity is the predominant risk factor associated with this type of stroke with $O R=5.8$. The study concluded a history of hypertension and physical inactivity is an independent risk factor associated with this type of stroke. Recommendations from this study aimed to hospitals to improve education activities to prevent risk factors for stroke. Besides increasing the role of nurses in the delivery of nursing services, where nurses care focuses on the health needs of patients holistically.

Keywords: Physical activity, hypertension, risk factors, \& stroke 


\section{PENDAHULUAN}

Stroke atau dikenal dengan penyakit serebrovaskuler, merupakan penyakit neurologik yang terjadi karena gangguan suplai darah menuju (Black and Hawk, 2009). Ada dua tipe stroke yaitu stroke hemorhagic dan stroke iskemik. Stroke iskemil banyak disebabkan karena trombotik atau sumbatan emboli, sedangkan stroke hemorhagic disebabkan oleh perdarahan akibat pecahnya pembuluh darah di suatu bagian otak.

Angka kejadian stroke meningkat seiring dengan bertambahnya usia, semakin tinggi usia seseorang semakin tinggi kemungkinan stroke (Yayasan Stroke Indonesia, 2012). Namun jumlah penderita stroke dibawah usia 45 tahun juga terus meningkat. WHO memprediksi bahwa kematian akibat stroke akan meningkat seiring dengan kematian akibat penyakit jantung dan kanker kurang lebih 6 juta pada tahun 2010 menjadi 8 juta di tahun 2030 (American Heart Association, 2010).

Menurut Yayasan Stroke Indonesia (YASTROKI) (2012), jumlah penderita stroke di Indonesia terbanyak dan menduduki urutan pertama di Asia. Stroke juga merupakan penyebab kecacatan serius menetap nomor 1 di seluruh dunia.

Hasil data Riset Kesehatan Dasar (Rikesda) tahun 2013 menemukan prevalensi stroke di Indonesia sebesar 12,1 per 1.000 penduduk. Angka tersebut naik sebesar 8,3\% dibandingkan Rikesda tahun 2007.

Perubahan gaya hidup; pola makan terlalu banyak gula, garam, dan lemak; serta kurang beraktivitas adalah faktor risiko stroke. Banyak faktor yang menyebabkan penyakit stroke. Faktor-faktor tersebut meliputi faktor risiko yang tidak dapat diubah dan faktor risiko yang dapat diubah. Faktor risiko yang dapat diubah meliputi usia, jenis kelamin, ras dan genetik. Sedangkan faktor risiko yang dapat diubah diantarannya adalah hipertensi, merokok, obesitas, diabetes mellitus, tidak menjalankan perilaku hidup sehat, tidak melakukan medical check up secara rutin dan mengkonsumsi makanan yang mengandung banyak garam.

RSUD Indramayu merupakan salah satu rumah sakit rujukan terbesar di Kabupaten Indramayu. Data pasien stroke dari Januari sampai Desember 2014 sebanyak 658. Berdasarkan data tersebut dapat diketahui rata-rata pasien stroke yang dirawat di RSUD Indramayu per bulannya adalah sebanyak 54 pasien pe bulannya.

Faktor yang mempengaruhi terjadinya stroke sudah banyak diketahui. Namun faktor risiko utama jenis stroke pada pasien yang dirawat di RSUD Indramayu belum diketahui. Oleh karena itu, perlu dilakukan analisis lanjut untuk mengidentifikasi faktor risiko apa saja yang berkontribusi terhadap terjadinya stroke CVD-SH maupun stroke CVD-SNH. Tujuan analisis ini adalah untuk menentukan faktor risiko dominan terjadinya stroke CVD-SH maupun stroke CVD-SNH.

\section{METODE}

Metode penelitian yang digunakan adalah metode kuantitatif dengan menggunakan desain penelitian survei yaitu cross sectional study. Pengambilan data variabel independen dan dependen diambil pada saat yang sama atau penggunakan pendekatan satu waktu. Penelitian cross sectional merupakan penelitian epidemiologik yang paling sering digunakan (Pratiknya, 2007, hlm.164). Penelitian cross sectional merupakan penelitian non eksperimental dalam rangka mempelajari dinamika korelasi antara faktor-faktor risiko dengan efek yang berupa penyakit atau status kesehatan tertentu, dengan model pendekatan point time, artinya kedua jenis variabel diobservasi sekaligus pada saat yang sama (Pratiknya, 2007, hlm. 168).

Populasi pada penelitian ini adalah pasien yang dirawat di RSUD Indramayu dengan diagnosa medis stroke yang dirawat di ruang ICU dan ruang penyakit dalam RSUD Indramayu. Adapun rata-rata kejadian stroke setiap bulannya adalah sebanyak 54 kejadian. 
Jumlah sampel sebanyak 103 responden yang diambil menggunakan teknik non probability sampling yaitu consecutive sampling.

Penelitian ini menggunakan kuesioner yang berisi pertanyaan-pertanyaan tentang faktor ririko yang berhubungan dengan kejadian stroke. Pertimbangan etika penelitian yang digunakan untuk memastikan bahwa responden dilindungi meliputi prinsip manfaat beneficence), menghargai manusia (respect for human dignity), dan mendapatkan prinsip keadilan (right to justice) (Polit, Beck, \& Hungler, 2001; Nursalam, 2008).

Penelitian ini menggunakan data primer yang diperoleh langsung dari subjek penelitian, dengan sumber data bisa berasal dari pasien itu sendiri maupun dari keluarga yang menemani pasien saat dirawat (keluarga yang mengetahui riwayat sebelum pasien menderita stroke), jika pasien mengalami penurunan kesadaran. Prosedur pengambian data dengan cara memberikan kuesione penelitian kepada responden atau keluarganya. Selain dari jawaban yang diisikan di kuesioner, informasi juga diperoleh melalui wawancara.

Analisa data meliputi analisa univariat, bivariat dan multivariat. Analisa bivariat menggunakan uji Chi Square karena data berbentuk kategorik. Analisa multivariat dilakukan untuk mengetahui pengaruh secara bersama-sama variabel bebas mana yang berpengaruh paling besar terhadap variabel terikat dengan menggunakan uji regresi logistik berganda. Analisis multivariat dengan metode Backward Stepwi se. Semua variabel bebas yang terpilih $(p<0,25)$ dimasukkan bersama-sama ke dalam analisis regresi, dan yang menunjukkan nilai $\mathrm{p}<0,05$ dipilih menjadi model.

\section{HASIL}

Penelitian tentang faktor risiko yang berhubungan denga stroke dilaksanakan pada bulan Juni - Agustus 2016 dengan jumlah responden sebanyak 103 pasien. Responden adalah pasien stroke yang dirawat di ruang
ICU, Cengkir I dan Cengkir II (Ruang Penyakit Dalam) RSUD Indramayu.

\section{Analisis Univariat}

Hasil penelitian jumlah responden berdasarkan jenis stroke diketahui sebanyak 73 orang $(70,9,1 \%)$ responden dengan diagnosa medis stroke non hemoragik. Sedangkan berdasarkan karakteristik umur, jenis kelamin, pendidikan, dan pekerjaan diketahui sebanyak $52(50,5 \%)$ responden adalah dengan kategori dewasa (usia $<55$ tahun), sebanyak 57 (55,3 \%) responden berjenis kelamin laki-laki, sebanyak $76(73,8$ \%) responden berpendidikan Sekolah Dasar dan sebanyak 69 (67,0\%) responden bekerja.

Sementara berdasarkan karakteristik faktor risiko diketahui sebanyak 76 orang $(73,8,1 \%)$ responden ada riwayat keluarga, sebanyak $98 \quad(95,1 \%)$ responden tidak memiliki riwayat penyakit jantung, sebanyak $87(84,5 \%)$ responden memiliki riwayat penyakit hipertensi, sebanyak 75 (72,8 \%) responden tidak memiliki riwayat penyakit diabetes mellitus, sebanyak $54 \quad(52,4 \quad \%)$ responden tidak melakukan perilaku merokok, sebanyak 71 (68,9 \%) responden tidak memiliki riwayat obesitas, sebanyak 74 (71,8\%) responden memiliki kadar kolesterol darah normal $(<200 \mathrm{mg} / \mathrm{dl})$, dan sebanyak 77 $(74,8 \%)$ responden memiliki riwayat aktivitas sedang.

\section{Analisis Bivariat}

Analisis faktor risiko yang tidak dapat diubah meliputi faktor risiko umur, jenis kelamin, dan riwayat penyakit keluarga (keturunan). Sedangkan analisis faktor risiko yang dapat diubah meliputi faktor pendidikan, pekerjaan, riwayat penyakit jantung, riwayat hipertensi, riwayat diabetes mellitus, riwayat perilaku merokok, riwayat obesitas, kadar kolesterol darah dan riwayat aktivitas. 
Tabel 1. Hasil Analisis Hubungan Faktor Risiko Kejadian Stroke di RSUD Indramayu (n=103)

\begin{tabular}{|c|c|c|c|c|c|c|c|c|}
\hline \multirow{3}{*}{$\begin{array}{l}\text { Faktor } \\
\text { Risiko }\end{array}$} & \multirow{3}{*}{ Kategori } & \multicolumn{4}{|c|}{ Stroke } & \multirow{3}{*}{ OR } & \multirow{3}{*}{ 95\% CI } & \multirow{3}{*}{$\underset{\text { value }}{\mathbf{p}}$} \\
\hline & & \multicolumn{2}{|c|}{ CVD-SH } & \multicolumn{2}{|c|}{ CVD-SNH } & & & \\
\hline & & $\mathbf{n}$ & $\%$ & n & $\%$ & & & \\
\hline \multirow{2}{*}{ Umur } & $\begin{array}{l}\text { Dewasa }(<55 \\
\text { tahun) }\end{array}$ & 20 & 38,5 & 32 & 61,5 & \multirow[b]{2}{*}{2,563} & \multirow[b]{2}{*}{$1,054-6,233$} & \multirow[b]{2}{*}{0,059} \\
\hline & $\begin{array}{l}\text { Lansia ( } \geq 55 \\
\text { tahun) }\end{array}$ & 10 & 19,6 & 41 & 80,4 & & & \\
\hline \multirow{2}{*}{$\begin{array}{l}\text { Jenis } \\
\text { Kelamin }\end{array}$} & Laki-laki & 15 & 26,3 & 42 & 73,7 & \multirow{2}{*}{0,738} & \multirow{2}{*}{$0,315-1,732$} & \multirow{2}{*}{0,631} \\
\hline & Perempuan & 15 & 32,6 & 31 & 67,4 & & & \\
\hline \multirow{2}{*}{$\begin{array}{l}\text { Riwayat } \\
\text { Keluarga }\end{array}$} & Ada & 7 & 25,9 & 20 & 74,1 & \multirow{2}{*}{0,807} & \multirow{2}{*}{$0,300-2,171$} & \multirow{2}{*}{0,868} \\
\hline & Tidak Ada & 23 & 29,1 & 53 & 69,7 & & & \\
\hline \multirow{2}{*}{$\begin{array}{l}\text { Riwayat } \\
\text { Hipertensi }\end{array}$} & Ada & 29 & 33,3 & 58 & 66,7 & \multirow{2}{*}{7,500} & $0,944-$ & \multirow{2}{*}{0,035} \\
\hline & Tidak Ada & 1 & 6,3 & 15 & 93,8 & & 59,599 & \\
\hline \multirow{2}{*}{$\begin{array}{l}\text { Diabetes } \\
\text { Mellitus }\end{array}$} & Ada & 10 & 35,7 & 18 & 64,3 & \multirow{2}{*}{1,528} & \multirow{2}{*}{$0,605-3,861$} & \multirow{2}{*}{0,512} \\
\hline & Tidak Ada & 20 & 26,7 & 55 & 73,3 & & & \\
\hline \multirow{2}{*}{$\begin{array}{l}\text { Riwayat } \\
\text { Jantung }\end{array}$} & Ada & 2 & 40,0 & 3 & 60,0 & \multirow{2}{*}{1,667} & $0,264-$ & \multirow{2}{*}{0,627} \\
\hline & Tidak Ada & 28 & 28,6 & 70 & 71,4 & & 10,516 & \\
\hline \multirow{2}{*}{$\begin{array}{l}\text { Kadar } \\
\text { Kolesterol } \\
\text { Darah } \\
\end{array}$} & Tinggi & 13 & 44,8 & 16 & 55,2 & \multirow[b]{2}{*}{2,724} & \multirow[b]{2}{*}{$1,096-6,771$} & \\
\hline & Normal & 17 & 23,0 & 57 & 77,0 & & & 0,051 \\
\hline Perilaku & $\mathrm{Ya}$ & 14 & 28,6 & 35 & 71,4 & & & \\
\hline Merokok & Tidak & 16 & 29,6 & 38 & 70,4 & 1,053 & $0,449-2,467$ & 1,000 \\
\hline Aktivitas & Berat & 2 & 7,7 & 24 & 92,3 & & & \\
\hline Fisik & Ringan & 28 & 36,4 & 49 & 63,6 & 0,146 & $0,032-0,064$ & 0,011 \\
\hline & $\mathrm{Ya}$ & 12 & 37,5 & 20 & 62,5 & & & \\
\hline Obesitas & Tidak & 18 & 25,4 & 53 & 74,6 & 0,566 & $0,232-1,383$ & 0,307 \\
\hline
\end{tabular}

Analisa hubungannya dapat dilihat pada tabel 1. Umur terbukti tidak berhubungan secara bermakna dengan kejadian stroke CVD-SH maupun CVD-SNH $(\mathrm{p}=0,059$, dan OR $=2,563$, CI $95 \%=$ 1,054-6,233). Namun jika dilihat dari nilai OR, maka dapat diketahui responden yang berumur dewasa $(<55$ tahun) berisiko 2,56 kali terjadi stroke CVD-SH daripada stroke CVD-SNH diabandingkan responden yang berumur lansia ( $\geq 55$ tahun).

Jenis kelamin terbukti tidak berhubungan secara bermakna dengan kejadian stroke CVD-SH maupun CVD-SNH $(\mathrm{p}=0,631$, dan $\mathrm{OR}=0,738$, CI $95 \%=$ 0,315-1,732). Begitupula dengan riwayat keluarga $(\mathrm{p}=0,858$, dan $\mathrm{OR}=0,807$, CI 95 $\%=0,300-2,171)$ tidak berhubungan dengan kejadian stroke berhubungan secara bermakna dengan kejadian stroke CVD-SH maupun CVD-SNH.

Riwayat hipertensi terbukti berhubungan secara bermakna dengan kejadian stroke
CVD-SH maupun CVD-SNH ( $\mathrm{p}=0,035$, dan $\mathrm{OR}=7,500$, CI $95 \%=0,944-59,599)$. Responden yang memiliki riwayat hipertensi memiliki risiko 7,5 kali terjadi stroke CVDSH daripada stroke CVD-SNH dibandingkan responden yang tidak memiliki riwayat hipertensi.

Riwayat diabetes tidak berhubungan dengan kejadian stroke CVD-SH maupun CVD-SNH $(\mathrm{p}=0,512$, dan OR $=1,528$, CI $95 \%=0,605-3,861)$. Namun jika dilihat dari nilai OR, maka dapat diketahui responden yang memiliki riwayat diabetes mellitus memiliki risiko 1,5 kali terjadi stroke CVD-SH daripada stroke CVD-SNH.

Riwayat jantung tidak berhubungan secara bermakna dengan kejadian stroke CVD-SH maupun CVD-SNH $(\mathrm{p}=0,627$, dan $\mathrm{OR}=1,667$ CI $95 \%=0,264-10,516$ ). Namun jika dilihat dari nilai OR, maka dapat diketahui responden yang memiliki riwayat jantung berisiko hampir 2 kali terjadi stroke CVD-SH daripada stroke CVD-SNH. 
Kadar kolesterol darah tidak berhubungan dengan kejadian stroke CVDSH maupun CVD-SNH ( $\mathrm{p}=0,051$, dan OR $=2,724$ CI $95 \%=1,096-6,771)$. Namun jika dilihat dari nilai OR, maka dapat diketahui responden yang memiliki kadar kolesterol darah yang tinggi berisiko 2,7 kali terjadi stroke CVD-SH daripada stroke CVD-SNH, dibandingkan dengan responden yang memiliki kadar kolesterol darah normal.

Perilaku merokok tidak berhubungan secara bermakna dengan kejadian stroke CVDSH maupun CVD-SNH ( $p=1,000$, dan OR $=1,053$ CI $95 \%=0,449-2,467)$. Begitu pula dengan riwayat obesitas $(\mathrm{p}=0,307$, dan $\mathrm{OR}=$ $0,566$ CI $95 \%=0,232-1,383)$.

Sedangkan aktifitas fisik terbukti berhubungan secara bermakna dengan kejadian stroke CVD-SH maupun CVD-SNH $(\mathrm{p}=0,011$, dan $\mathrm{OR}=0,146$, CI $95 \%=$ 0,032-0,664). Namun jika dilihat dari nilai OR, menunjukkan bahwa responden yang memiliki riwayat aktivitas fisik yang berat berisiko hanya 0,15 kali terjadi stroke CVDSH daripada stroke CVD-SNH dibandingkan responden yang memiliki riwayat aktivitas sedang.

\section{Analisis Multivariat}

Analisis multivariat dilakukan untuk mengetahui pengaruh secara bersama-sama variabel bebas terhadap variabel terikat. Analisa menggunakan uji regresi logistik ganda dengan merode Backward Stepwise. Variabel yang memilki nilai $\mathrm{p}<0,25$ pada analisa bivariat dan variabel bebas yang bermakna secara biologis terhadap variabel terikat, maka akan masuk sebagai kandidat dalam uji regresi logistik. Adapun variabelnya terdiri dari 8 variabel, yaitu umur $(\mathrm{p}=0,059$, $\mathrm{OR}=2,563)$, riwayat hipertensi $(\mathrm{p}=0,035$, OR $=7,500)$, riwayat diabetes mellitus $(p=0,512$, $\mathrm{OR}=1,528)$, riwayat jantung $(\mathrm{p}=0,627 ; \mathrm{OR}=$ 1,667), kadar kolesterol darah $(\mathrm{p}=0,051 ; \mathrm{OR}=$ $2,724)$, perilaku merokok $(\mathrm{p}=1,000 ; \mathrm{OR}=$ $1,053)$, obesitas $(\mathrm{p}=0,307$; OR $=0,566)$, dan aktivitas ( $\mathrm{p}=0,011$; OR $=0,146)$.

Tabel 2. Faktor-faktor yang dimasukan dalam analisa multivariat

\begin{tabular}{lcc}
\hline \multicolumn{1}{c}{ Faktor Risiko } & $\mathrm{p}$ & OR \\
\hline Umur & 0,059 & 2,563 \\
Riwayat Hipertensi & 0,035 & 7,500 \\
Riwatar DM & 0,512 & 1,528 \\
Riwayat Jantung & 0,627 & 1,667 \\
Kadar Kolesterol Darah & 0,051 & 2,724 \\
Perilaku Merokok & 1,000 & 1,053 \\
Obesitas & 0,307 & 0,566 \\
Aktivitas Fisik & 0,011 & 0,145 \\
\hline
\end{tabular}

Hasil analisa multivariat menunjukkan ada 1 (satu) variabel independen yang dinilai berpengaruh terhadap kejadian stroke CVDSH dan stroke CVD-SNH, yaitu aktivitas fisik ( $\mathrm{p}=0,046$; OR adjusted 5,848; $95 \%$ CI 1,036 - 33,014). Adapun selengkapnya dapat dilihat pada tabel 3 .

Berdasarkan hasil analisa multivariat didapatkan OR dari variabel aktivitas adalah 5,8 artinya orang yang memiliki aktivitas berat memiliki resiko terkena stroke CVD-SH sebesar 5,8 kali lebih tinggi dari CVD-SNH bila dibandingkan yang memilki aktivitas sedang setelah dikontrol pendidikan, riwayat hipertensi, riwayat keluarga, riwayat DM, riwayat jantung, kadar kolesterol darah, obesitas, dan umur.

Tabel 3. Model analisis multivariat faktor risiko kejadian stroke di RSUD Indramayu ( $\mathrm{n}=103)$

\begin{tabular}{lcccccccc}
\hline \multirow{2}{*}{ Variabel } & \multirow{2}{*}{ B } & \multirow{2}{*}{ S.E. } & \multirow{2}{*}{ Wald } & df & \multirow{2}{*}{ Sig. } & \multirow{2}{*}{ Exp (B) } & \multicolumn{2}{c}{ 95\% C.I Exp (B) } \\
\hline Aktivitas & 1,766 & 0,883 & 4,000 & 1 & 0,046 & 5,848 & 1,036 & 33,014 \\
\hline
\end{tabular}

\section{PEMBAHASAN}

Umur merupakan faktor risiko kejadian stroke yang tidak dapat diubah, dimana semakin meningkatnya umur, maka risiko terjadi stroke juga akan semakin meningkat. Hal ini disebabkan semakin bertambahnya umur maka sistem pembuluh darah mengalami pemunduran sehingga berisiko 
mengalami stroke. Menurut Wahjoepramono (2005), mengatakan bahwa berdasarkan hasil statistik ditemukan faktor umur menjadi faktor risiko 2 kali lipat setelah usia $\geq 55$ tahun. Dan menurut hasil penelitian pada Framingham Study menunjukkan risiko stroke akan meningkat sebesar $20 \%, 32 \%$, dan $83 \%$ pada kelompok umur 45 - 55 tahun, 55 - 64 tahun, dan $65-74$ tahun.

Namun hasil penelitian menunjukkan bahwa umur tidak berhubungan dengan kejadian jenis stroke $(p=0,059,95 \% \mathrm{CI})$. Hal ini menunjukkan bahwa faktor usia tidak menjadi faktor determinan terjadinya stroke hemorhagic maupun stroke non hemorhagic. Hal ini senada dengan hasil penelitian Sitorus, Hadisaputra, dan Kustiowati (2010) yang menemukan bahwa umur merupakan faktor risiko yang secara mandiri tidak berhubungan dengan kejadian stroke.

Serangan penyakit stroke saat ini telah bergeser ke umur yang lebih muda yaitu sekitar 40 tahun. Sesuai dengan hasil penelitian yang dilakukan oleh Riyadina dan Rahajeng (2013) bahwa risiko mengalami stroke lebih tinggi pada responden yang berumur $35-44$ tahun. Hal senada jg disampaikan oleh Ghani, Mihardja dan Delima (2016) yang mengatakan bahwa proporsi responden terbanyak pada usia 35 44 tahun, disusul kelompok usia $15-24$ tahun dimana stroke muncul pada kelompok usia muda sebesar $0,3 \%$.

Stroke dapat menyerang siapa saja, bahkan yang berusia muda. Menurut hasil penelitian yang dilakukan oleh Burhanuddin, Wahiduddin, dan Jumriani (2013) ditemukan bahwa umur responden lebih banyak adalah umur 38 - 40 tahun. Sesuai dengan hasil penelitian menunjukkan proporsi kelompok umur paling banyak adalah pada umur dewasa $(<55$ tahun) sebanyak 51,5\%, dimana sebanyak $61,5 \%$ mangalami kejadian stroke CVD-SNH. Hasil analisa lanjut didapatkan nilai OR 2,56, artinya orang yang berumur dewasa $(<55$ tahun) memiliki risiko terkena stroke CVD-SH 2,56 kali daripada stroke
CVD-SNH dibanding pada usia lanjut $(\geq 55$ tahun).

Responden pada penelitian ini 73,7\% berjenis kelamin laki-laki. Stroke diketahui lebih banyak diderita laki-laki dibanding perempuan. American Heart Association meng-ungkapkan bahwa serangan stroke lebih banyak terjadi pada laki-laki dibandingkan perempuan dibuktikan dengan hasil penelitian yang menunjukkan bahwa prevalensi kejadian stroke lebih banyak pada laki-laki (Goldstein, dkk., 2006).

Menurut penelitian Ghani, Mihardja dan Delima (2016) mendapatkan hasil yang berbeda, dimana besar sampel perempuan sedikit lebih banyak dari laki-laki. Namun proporsinya terlihat sama antara laku-laki dan perempuan yaitu sebesar $1,2 \%$. Hasil penelitian ini sesuai dengan yang disampaikan Sacco, et al. (1997) bahwa kejadian stroke pada laki-laki 1,25 kali lebih banyak dibandingkan pada perempuan. Pernyataan Sacco, et al. ini didukung oleh American Heart Association/AHA (2006) bahwa serangan stroke lebih banyak terjadi pada laki-laki dibandingkan perempuan dibuktikan dengan hasil penelitian yang menunjukkan bahwa kejadian stroke pada laki-laki 81,7 per 100.000 dan perempuan 71,8 per 100.000. Kondisi ini diduga berhubungan dengan lifestyle dan berkaitan dengan faktor risiko yang lain yaitu merokok, konsumsi alkohol dan dislipidemia.

Namun dari hasil penelitian ini ditemukan tidak ada hubungan yang bermakna antara jenis kelamin denga kejadian stroke CVD-SH maupun CVD-SNH ( $\mathrm{p}$ value 0,631, $95 \% \mathrm{CI})$. Artinya stroke CVD-SH maupun CVD-SNH dapat terjadi baik pada laki-laki maupun perempuan.

Riwayat keluarga merupakan salah satu faktor risiko yang berhubungan dengan kejadian stroke. Namun riwayat keluarga bukan merupakan faktor risiko independen yang menyebabkan stroke. Penelitian ini menunjukkan hasil tidak ada hubungan yang signifikan antara riwayat keluarga dengan 
kejadian stroke (p value 0,858, $95 \%$ CI). Responden yang memiliki riwayat keluarga (keturunan) ditemukan sebanyak 27 ((26,2 \%) dari 103 responden terkena yang serangan stroke. Dilihat dari OR juga sangat kecil yaitu 0,8 , yang artinya responden yang memiliki riwayat keluarga berisiko 0,8 kali untuk terjadi stroke CVD-SH daripada stroke CVDSNH.

Sementara itu hasil penelitian yang dilakukan oleh Sitorus, dkk (2010) dimana riwayat penyakit stroke di keluarga terbukti memiliki hubungan yang bermakna dengan kejadian stroke di usia muda $(\mathrm{p}=0,02$ dan $\mathrm{OR}=2,9$ Risiko untuk terjadinya stroke pada usia muda pada responden dengan ada riwayat stroke pada keluarga 2,9 kali lebih besar dibanding dengan tidak ada riwayat stroke pada keluarga.

Responden yang menderita kelainan jantung dalam penelitian ini sebanyak 5 orang (4,9\%) lebih sedikit dibandingkan yang tidak mengalami riwayat jantung 98 orang $(95,1$ \%). Hasil analisa lanjut diketahui tidak ada hubungan yang signifikan antara riwayat jantung dengan kejadian stroke CVD-SH dan stroke CVD-SNH. Artinya tidak ada hubungan antara riwayat jantung dengan kejadian stroke. Namun dari nilai OR diketahui orang yang memiliki riwayat jantung berisiko 1,7 kali mengalami stroke CVD-SH daripada stroke CVD-SNH dibandingkan yang tidak memiliki riwayat jantung.

Penelitian yang dilakukan oleh Kristiyawati (2008) didapatkan hasil yang sama, yaitu tidak ada hubungan yang signifikan antara kelainan jantung dengan kejadian stroke $(\mathrm{p}=0,156)$. Responden dengan kelainan jantung berisiko 2,272 kali terkena serangan stroke bila dibandingkan dengan responden yang tidak mengalami kelainan jantung $(\mathrm{OR}=2,272 ; 95 \%$ CI 0,852 - 6,059). Sedangkan penelitian yang dilakukan Isparyanto (2006) di Yogyakarta melaporkan bahwa responden dengan kelainan jantung (atrial fibrilasi) berisiko 2,28 kali terkena serangan stroke dibandingkan dengan responden yang tidak terkena atrial fibrilasi (OR $=2,28 ; 95 \%$ CI 1,89-2,75).

Namun menurut hasil penelitian Anwar (2004) Kelainan jantung terutama yang berhubungan dengan timbulnya emboli. Atrial fibrilasi adalah kasus yang paling sering terjadi dan berisiko $3-4$ kali terjadi serangan stroke. Atrial fibrilasi non valvuler merupakan penyebab emboli, dimana emboli adalah salah satu faktor pencetus atrial fibrilasi. Hal tersebut dipertegas oleh AHA/ASA (2006), bahwa individu yang menderita atrial fibrilasi, $2-4 \%$ mengalami serangan stroke.

Tekanan darah merupakan salah satu faktor yang berkontribusi terhadap kejadian stroke. Dan hipertensi merupakan faktor resiko utama, baik pada stroke iskemik maupun stroke hemoragik. Makin tinggi tekanan darah, makin tinggi kemungkinan terjadinya stroke, baik perdarahan maupun iskemik. Menurut Riyadina dan Rahajeng (2013) mengatakan bahwa masyarakat yang menderita hipertensi berisiko 4 kali lebih besar untuk mengalami penyakit stroke $(\mathrm{OR}=$ 4,$20 ; 95 \%$ CI) dibandingkan yang tidak menderita hipertensi.

Hasil penelitian diketahui responden yang mengalami hipertensi baik sebelum stroke maupun saat terjadinya stroke, yaitu sebanyak 84,5 \%. Hasil analisa lanjut diketahui ada hubungan secara bermakna antara hipertensi dengan kejadian stroke CVD-SH maupun CVD-SNH ( $\mathrm{p}=0,035, \alpha=$ $0,05)$. Berdasarkan nilai OR maka dapat diketahui bahwa responden yang memiliki riwayat hipertensi akan berisiko 7,5 kali terjadi stroke CVD-SH daripada stroke CVDSNH dibandingkan responden yang tidak memiliki riwayat hipertensi.

Hasil ini sesuai dengan penelitian yang dilakukan oleh Sitorus, dkk (2010) yang mengatakan ada riwayat hipertensi terbukti memiliki hubungan yang bermakna dengan kejadian stroke pada usia muda dengan $\mathrm{p}=$ $0,002(\mathrm{p}<0,05)$ dan $\mathrm{OR}=4,33$, CI $95 \%=$ 
1,78 -10,52. Risiko untuk terjadinya stroke pada usia muda pada responden dengan ada riwayat hipertensi 4,33 kali lebih besar dibanding dengan tidak ada riwayat hipertensi. Begitupula menurut penelitian Riyadina dan Rahajeng (2013) mengatakan bahwa masyarakat yang menderita hipertensi berisiko 4 kali lebih besar untuk mengalami penyakit stroke $(\mathrm{OR}=4,20$; CI $95 \%=2,20-8,03$.

Tekanan darah yang tinggi dapat mempengaruhi autoregulasi aliran darah ke otak yang berdampak pada percepatan muncul dan bertambah hebatnya aterosklerosis serta munculnya lesi spesifik pada arteri intraserebral. Faktor timbulnya lesi ini merupakan gejala yang sulit dipahami, namun stenosis $>70 \%$ secara linier berhubungan dengan risiko terjadinya infark serebral (Mohr, J.P., et al., 2007). Namun penelitian yang dilakukan oleh Goldstein, et al. (2006) mengatakan bahwa semakin tinggi tekanan darah semakin tinggi risiko terjadi stroke, peningkatan tekanan darah terutama tekanan sistolik akan meningkat seiring dengan peningkatan usia.

Diabetes mellitus merupakan penyakit metabolik dengan karakteristik hiperglikemia. Individu dengan diabetes mellitus mempunyai kepekaan yang tinggi terhadap terjadinya aterosklerosis dan berhubungan dengan faktor risiko aterogenik yang lain khususnya hipertensi, obesitas dan dislipidemia (AHA, 2006).

Hasil penelitian diketahui responden yang menderita diabetes mellitus sebanyak 28 responden $(27,2 \%)$. Dari hasil tersebut sebanyak 64,3 \% mengalami stroke CVDSNH. Namun dari hasil analisa lanjut ditemukan tidak ada hubungan yang signifikan antara riwayat diabetes mellitus dengan kejadian stroke CVD-SH dan stroke CVD-SNH (P value 0,512, $95 \% \mathrm{CI}$ ). Dari hasil analisa OR diketahui bahwa responden yang menderita diabetes mellitus memiliki risiko 1,5 kali terjadi stroke CVD-SH daripada stroke CVD-SNH dibandingkan yang tidak memiliki riwayat diabetes mellitus.
Menurut Kritiawati (2008) mengatakan bahwa merokok merupakan salah satu faktor risiko terjadinya penyakit kardiovaskular dan stroke. Insiden stroke akan meningkat bila dikombinasikan dengan faktor risiko yang lain terutama hipertensi. Rokok mengandung lebih dari 4000 jenis bahan kimia yang di antaranya bersifat karsinogenik atau mempengaruhi sistem vaskular. Merokok meningkatkan terjadinya trombus, karena terjadinya arterosklerosis (AHA/ASA, 2006).

Hasil penelitian ditemukan sebanyak 49 responden ( $47,6 \%$ ) yang merokok, ditemukan sebanyak 35 (71,4 \%) mengalami stroke CVD-SNH. Hasil analisa diketahui $\mathrm{p}=$ 1,000 $(\alpha=0,05)$, maka dapat disimpulkan riwayat perilaku merokok tidak berhubungan dengan terjadinya stroke CVD-SH maupun stroke CVD-SNH. Orang yang merokok berisiko 1,05 kali terjadi stroke CVD-SH daripada stroke CVD-SNH (OR $=0,053,95$ $\%$ CI 0,449 - 2,467). Hal ini diperkuat Framingham, Cardiovascular Health Study, dan Honolulu Heart Study yang mengidentifikasi bahwa kebiasaan merokok merupakan faktor risiko potensial untuk terjadi stroke iskemik, berhubungan dengan perkiraan dua kali lipat risiko stroke iskemik. Selain itu, merokok telah secara jelas berhubungan dengan $2-4$ kali lipat peningkatan risiko stroke hemoragik (Riyadina dan Rahajeng, 2013)..

Hal ini menunjukkan bahwa perilaku merokok bukan satu-satunya faktor yang mempengaruhi terjadinya stroke. Kondisi ini dipengaruhi oleh karakteristik jenis kelamin dan lokasi dalam penelitian, dimana jumlah proporsi responden laki-laki dan perempuan hampir sama, khususnya responden perempuan semuanya tidak merokok. Hal itu sesuai dengan kebudayaan di Indramayu, dimana perempuan pada umumnya tidak merokok. Pengambilan sampel yang dilakukan di rumah sakit sehingga belum mewakili populasi penderita. Selain itu dalam kuesioner, variabel perlaku merokok terdapat keterbatasan untuk mantan perokok yang 
tidak ditanyakan tentang dose response yaitu berapa jumlah batang per hari pada waktu merokok. Meskipun mantan perokok potensial meningkatkan risiko yang tidak menunjukkan hubungan yang bermakna.

Obesitas berhubungan denegan tingginya tekanan darah dan kadar gula darah, jantung bekerja lebih keras untuk memompa darah keseluruh tubuh, sehingga dapat meningkatkan tekanan darah. Oleh karena itu obesitas berkontribusi juga terhadap terjadinya stroke. Sesuai dengan hasil penelitian Ghani, Mihardja dan Delima (2016) menemukan bahwa responden dengan status gizi normal lebih banyak, demikian juga yang tidak obesitas sentral. Namun terlihat proporsi stroke lebih tinggi pada yang obesitas dan obesitas sentral.

Namun tidak sesuai dengan hasil penelitian, dimana ditemukan hasil tidak ada hubungan antara obesitas dengan kejadian stroke CVD-SH dan stroke CVD-SNH (p value $0,307,95 \% \mathrm{CI}$ ). Hasil ini senada dengan penelitian yang dilakukan oleh Nurfaida, Munawir dan Suarnianti (2013) yang menyimpulkan tidak ada hubungan antara obesitas dengan kejadian Non Hemoragic Stroke (NHS) di Rumah Sakit Tingkat II Pelamonia Makasar ( $\mathrm{p}=0,419, \alpha=$ $0,05)$. Menurutnya asil penelitian ini juga didukung oleh penelitian Sahruni (2012) yang mengemukakan bahwa obesitas tidak menunjukkan hubungan yang positif dengan kejadian stroke.

Hubungan langsung obesitas dengan stroke memang belum jelas. Namun obesitas biasanya berhubungan dengan pola makan, DM tipe 2, peningkatan kadar kolesterol dan peningkatan tekanan darah yang memicu terjadinya proses aterosklerosis. Terutama yang mengalami central obesitas (obesitas perut).

Jumlah responden dengan kadar kolesterol darahnya tinggi ( $>200 \mathrm{mg} / \mathrm{dl}$ ) dalam penelitian ini sebanyak 29 orang $(28,2 \%)$ jauh lebih sedikit dibandingkan yang memiliki kadar kolesterol darah normal yaitu
74 orang $(71,8 \%)$. Hasil ini senada dengan penelitian Aliah dan Widjaja (2000), dimana responden yang mengalami dislipidemia sebanyak $23 \%$ dan yang tidak mengalami dislipidemia sebanyak 77\%. Analisa lebih lanjut menunjukkan tidak ada hubungan antara kadar kolesterol darah dengan kejadian stroke CVD-SH maupun CVD-SNH ( $p=$ $0,051, \alpha=0,05)$, dan risiko stroke pada responden yang memiliki kadar kolesterol darah yang tinggi berisiko 2,7 kali terjadi stroke CVD-SH daripada CVD-SNH (OR = 2,724; 95\% CI 1,096-6,771).

Kadar kolesterol total dan Low Density Lipoprotein (LDL) yang meningkat berkaitan erat dengan terjadinya aterosklerosis. Kolesterol LDL yang tinggi merupakan risiko terjadinya stroke iskemik. Dan kadar kolesterol LDL yang lebih dari $150 \mathrm{mg} / \mathrm{dL}$ meningkatkan risiko terjadinya sumbatan pembuluh darah otak. Menurut AHA/ASA (2006), mengatakan bahwa kejadian stroke meningkat pada penderita dengan kadar kolesterol total di atas $240 \mathrm{mg} / \mathrm{dL}$. Setiap kenaikan kadar kolesterol total $38,7 \mathrm{mg} / \mathrm{dL}$ meningkatkan risiko stroke sebanyak $25 \%$.

Sesuai yang dikemukanan oleh Riyadina dan Rahajeng (2013) mengatakan bahwa kondisi sindrom metabolik responden yang tidak normal dapat menjadi pencetus serangan stroke. Sindrom metabolik yang merupakan faktor risiko stroke meliputi tekanan darah tinggi, gula darah meningkat, kegemukan dan dislipidemia.

Hasil penelitian ini diketahui sebanyak 77 responden $(74,8 \%)$ memiliki riwayat aktivitas sedang, dan sebanyak 26 responden $(25,2 \%)$ memiliki riwayat aktivitas berat. Dari 26 responden yang memiliki riwayat aktivitas berat, diketahui sebanyak 24 (92,3 $\%)$ responden mengalami stroke CVD-SNH. Hasil analisa diketahui ada hubungan yang signifikan antara aktivitas fisik dengan kejadian stroke $(\mathrm{p}=0,011, \alpha=0,05$; OR $=$ 0,146, $95 \%$ CI 0,032 - 0,664) Hasil penelitian ini tidak sejalan dengan hasil penelitian yang dilakukan oleh Siswanto 
(2005) tidak didapatkan hubungan yang bermakna secara statistik antara variabel umur, jenis kelamin, riwayat stroke pada keluarga, kadar gula darah sewaktu, kadar gula darah puasa, kadar kolesterol total dalam darah >200 mg/dl, kelainan jantung, kebiasaan merokok, dan aktivitas fisik.

Ketidakaktifan fisik merupakan faktor risiko utama untuk terjadinya serangan jantung dan stroke, yang ditandai dengan penumpukan substansi lemak, kolesterol, kalsium dan unsur lain yang mensuplai darah ke otot jantung dan otak, yang berdampak terhadap menurunnya aliran darah ke otak maupun jantung. Serangan jantung dan stroke akan lebih cepat terjadi apabila dikombinasi dengan faktor risiko lain yaitu obesitas, hipertensi, dislipidemia dan diabetes mellitus.Menurut AHA (2002) mengatakan bahwa ketidakaktifan fisik meningkatkan risiko stroke dan penyakit jantung hingga $50 \%$.

Aktifitas dalam penelitian ini dilihat dari aktifitas sehari-hari yang meliputi aktifitas dalam bekerja atau melaksanakan pekerjaan rumah. Berdasarkan hasil penelitian diketahui sebanyak $67 \%$ responden bekerja. Dan dari pekerjaan yang dimiliki sebagian besar adalah sebagai petani. Seorang petani biasanya melakukan aktivitas mencangkul, mengangkut padi, dan membajak sawahnya. Kegiatan tersebut merupakan aktivitas dalam kategori berat. Dan sesuai dengan kebiasaan, aktivitas bertani dan bercocok tanam dilakukan setiap hari tanpa ada libur, lebihlebih jika tiba musim panen.

Sedangkan responden yang tidak bekerja meliputi ibu rumah tangga dan lansia yang sudah tidak bekerja lagi. Sebagian dari responden yang beraktivitas dalam kategori sedang meliputi juga pekerjaan sebagai pedagang, wiraswasta, dan pegawai.

Hasil analisis multivariat diketahui bahwa variabel aktivitas fisik berhubungan secara bermakna dengan jenis stroke. Sedangkan variabel pendidikan, riwayat hipertensi, riwayat DM, riwayat jantung, dislipidemia, obesitas, dan umur sebagai variabel confounding. Dan dari hasil analisa OR diketahui orang yang memiliki aktivitas berat memiliki resiko terkena stroke CVD-SH sebesar 5,8 kali lebih tinggi dari CVD-SNH bila dibandingkan yang memilki aktivitas sedang setelah dikontrol pendidikan, riwayat hipertensi, riwayat keluarga, riwayat DM, riwayat jantung, dislipidemia, obesitas, dan umur.

Masih beragamnya hasil penelitian yang membahas tentang faktor risiko stroke, menuntuuntuk tetap lebih memperhatikan faktor - faktor risiko yang sudah terbukti menjadi pencetus penyakit stroke. Meskipun menurut Ghani, Mihardja, dan Delima (2016) mengatakan bahwa faktor risiko dominan penyakit stroke secara nasional belum ada, maka perlu dilakukan analisis agar intervensi pencegahan melalui deteksi dini dan pencegahan/terapi secara umum dapat dilakukan dengan tepat.

Diharapkan rumah sakit adalah melakukan penyuluhan atau pemberian informasi kepada masyarakat tentang upaya pencegahan sekunder (pola hidup sehat, pengendalian faktor risiko) dapat dilakukan secara langsung berupa konseling atau tidak langsung berupa media seperti iklan, poster / brosur.

Pengobatan diarahkan pada pengendalian faktor risiko seperti hipertensi, diabetes melitus, penyakit jantung untuk mempercepat penyembuhan. Selain itu perlu ditingkatkan kewaspadaan perawat terhadap kondisi pasien terutama pasien yang memiliki faktor risiko dan pasien yang sudah menderita stroke, sehingga kejadian stroke dan stroke berulang dapat dihindarkan. Kewaspadaan ini akan diperoleh apabila perawat menjalankan peran sebagai pemberi pelayanan keperawatan, dimana perawat memfokuskan asuhan pada kebutuhan kesehatan pasien secara holistik. 


\section{SIMPULAN}

Tidak ada hubungan secara signifikan antara faktor umur, jenis kelamin, riwayat pendidikan, riwayat diabetes mellitus, riwayat keluarga, riwayat jantung, riwayat perilaku merokok, kadar kolesterol darahm dan riwayat obesitas dengan kejadian stroke CVD-SH maupun CVD-SNH ( $p>0,05,95 \%$ $\mathrm{CI})$.

Ada hubungan secara signifikan antara faktor riwayat stroke dan aktivitas fisik dengan kejadian stroke CVD-SH maupun CVD-SNH ( $\mathrm{p}<0,05,95 \%$ CI). Variabel aktivitas fisik adalah variabel yang dominan mempengaruhi secara bermakna jenis stroke setelah dikontrol variabel pendidikan, riwayat hipertensi, riwayat DM, riwayat jantung, dislipidemia, obesitas, dan umur sebagai variabel confounding.

\section{DAFTAR PUSTAKA}

American Heart Association/AHA. (2002). Risk factors. http://stroke.ahajournals. org/cgi/content/full/28/7/1507 diperoleh tanggal 14 September 2016

American Heart Association/American Stroke Association (AHA/ASA). (2006). Primary prevention of ischemic stroke. http://stroke.ahajournals.org/cgi/content/ full/37/6/1583\# FIG1173987 diperoleh tanggal 4 September 2016.

Black, M.J. \& Hawk, H.J. (2009). Medical surgical nursing: clinical management for positive outcome, Elsevier, Singapura.

Burhanuddin, M., Wahiduddin, dan Jumriani. (2013). Faktor Risiko Kejadian Stroke pada Dewasa Awal (18-40 Tahun) di Kota Makasar Tahun 2010-2012.

Ghani, L., Mihardja, L. K., dan Delima (2016). Faktor Risiko Dominan Stroke di Indonesia. Buletin Penelitian Kesehatan. Vol 44 No. 1, Maret 2016: 49-58.

Goldstein, L.B., Adams, R., Alberts, M. J., Appel, L. J., Brass, L. M., Bushnell, C. D., Culebras, A. (2006).
Isparyanto, W. (2006). Penyakit jaringan pendukung gigi (periodontal disease) sebagai faktor risiko stroke iskemik. http://digilib.litbang.depkes.go.id/go.php ?id= jkpkbppk-gdl-res-2007-winangkuis2348\&q=stroke diperoleh 27 Agustus 2016.

Kristiawati, S. R. (2008). Analisis faktor risiko yang berhubungan dengan kejadian stroke di Rumah Sakit Panti Wilasa Citarum Semarang. Tesis.

Nurfaida, Munawir dan Suarnianti (2013). Faktor-faktor yang berhubungan dengan kejadian non haemoragic stroke (NHS) pada rumah sakit TK II Pelamonia Makasar. Library.stikesnh.ac.id. Volume 2 No 5 tahun 2013.

Nursalam. (2008). Konsep \& Penerapan Metodologi Penelitian Ilmu Keperawatan, Jakarta: Salemba Medika

Polit, D.F., \& Beck, C.T. (2006). Essentials of nursing research: Method, appraisal and utilization. Sixth Edition. Philadelphia: Lippincot Williams \& Wilkins.

Riyadina, W. dan Rahajeng, E. (2013). Determinan Penyakit Stroke. Journal FKM UI.

Sacco, et al,. (1997). Risk factors for ischemic stroke. http://www.americanheart.org/ presenter.jhtml?identifier $=4716$ diperoleh tanggal 14 September 2016.

Siswanto, Y. (2005). Beberapa faktor risiko yang mempengaruhi kejadian stroke berulang (studi kasus di RS DR. Kariadi Semarang. dinduh dari esprints.undip. ac.id tanggal 28 November 2016.

Sitorus, R.J., Hadisaputro, S., dan Kustiowati, E. (2010). Faktor-faktor Risiko yang Mempengaruhi Kejadian Stroke pada Usia Muda Kurang dari 40 Tahun di Rumah Sakit di Kota Semarang. (http://esprint.undip.ac.id/6482/1/

Rico_Januar_Sitorus.pdf) diakses pada 27 April 2015.

Wahjoepramono, E. J. (2005). Stroke tatalaksana fase akut. Jakarta: Universitas Pelita Harapan. 
World Health Organization (WHO). (2011)

Non-communicable disease surveillance

and prevention in South-East Asia Region. India

YASTROKI (2012). Jumlah Penderita Stroke

Semakin Meningkat 